\title{
Entre meios e metáforas: uma reflexão sobre processos de criação e (re)significação do olhar por via de imagens técnicas
}

\section{Noeli Batista dos \\ SANTOS}

\section{Resumo}

No conto de ficção cientifica "O Homem Bicentenário" do escritor Isaac Asimov, o robô, personagem principal, é diferenciado de seus iguais, robôs, quando consegue transformar matéria-prima em objeto portador de significado. Neste processo, o robô ganha um nome: Andrew. Ao ganhar um nome a máquina dotada de saber sensível inicia sua jornada na busca por tornar-se homem. Nesta jornada, o personagem segue (re)significando seus saberes, suas relações sociais, sua relação com o próprio corpo. No primeiro semestre do ano de 2007, ministrei o curso "Laboratório de Criação de Imagens em Mídias Digitais" oferecido pelo Centro de Estudo e Pesquisa "Ciranda da Arte". O propósito deste curso foi discutir os diferentes espaços que as imagens técnicas ocupam em nossa contemporaneidade. Neste curso, participaram um grupo de professores da Rede Estadual de Ensino de Goiás integrando discussões que abrangeram relações de ensino, construção e compreensão de imagens técnicas. Neste processo, cada professor/aluno, transitou entre o "ser" "produtor", "artista", "crítico" e "expectador", encontrando nestes espaços (concretos e virtuais) de aprendizagem a possibilidade de também ser autor no processo de criação, de suas poéticas visuais mediadas pelo uso do aparelho. Entre metáforas que envolvem as relações entre máquina e saber sensível, inspiradas no conto "O Homem Bicentenário", a proposta deste projeto é buscar compreender que tipo de (re) significações do olhar esse grupo de ex-alunos passou a assimilar em suas práticas pedagógicas ou em suas vivências diárias. É também intenção deste projeto promover a reflexão sobre o exercício de criação enquanto metáfora para processos de humanização (saber sensível) através imagens técnicas.

Palavras-chave: Ensino, imagem técnica, poéticas visuais. 